\title{
Epidemiological report on Acute Encephalitis Syndrome (AES)/Japanese Encephalitis (JE) outbreak in Bihar \& planning perspectives for its control
}

\author{
Ragini Mishra ${ }^{1, ~ *, ~ G a n g a ~ K u m a r ² ~}$ \\ ${ }^{1}$ State Health Society, Bihar, India \\ ${ }^{2}$ Bihar State Building Construction Corporation and Building Construction Department, Govt. of Bihar, India
}

Email address:

ragini330@gmail.com (R. Mishra)

\section{To cite this article:}

Ragini Mishra, Ganga Kumar. Epidemiological Report on Acute Encephalitis Syndrome (AES)/Japanese Encephalitis (JE) Outbreak in Bihar \& Planning Perspectives for Its Control. American Journal of Health Research. Vol. 2, No. 6, 2014, pp. 404-410.

doi: 10.11648/j.ajhr.20140206.24

\begin{abstract}
Acute Encephalitis Syndrome (AES) is a major public health problem in Bihar claiming thousands of lives every year in Bihar. Initially, the disease outbreak was focused in Muzaffarpur district of Bihar but recent trend shows that disease outbreak has spread its foci in many other districts as well. AES cases were recorded from district reporting units comprising Govt Medical College \& Hospitals and few private hospitals in prescribed format under Integrated Disease Surveillance Control Programme of the State. In 2014, till $17^{\text {th }}$ Oct, 928 cases and 314 deaths due to AES was reported in Bihar.JE cases among the AES cases constituted only $2 \%$ of the cases. Age group most affected was $0-4$ and males were more affected than females. Case fatality rate in the AES outbreak was 34 and no deaths were reported due to JE. Outbreak peak was from $10^{\text {th }}$ June to $19^{\text {th }}$ June. The report overviews analytical comparison of yearly AES outbreak in Bihar based on descriptive epidemiological analysis. JE vaccination coverage in Bihar was also analyzed to co-relate its impact on curbing the AES cases. Although JE vaccination has reduced the incidence of JE cases but it has little impact on curbing AES cases. As the etiological confirmation of the disease outbreak has still not been established, better control strategies are required. Inter-sectoral coordination with various departments may also help in control and management of the disease outbreak.
\end{abstract}

Keywords: Acute Encephalitis Syndrome, Japanese Encephalitis, Descriptive Epidemiology, Outbreak, Etiology

\section{Introduction}

Japanese Encephalitis (JE) is caused by a virus which is transmitted through the bite of infected mosquitoes (Culex tritaeniorhyncus and vishnui) and is one of the common causes of AES (1). Acute encephalitis syndrome (AES) is defined as the acute-onset of fever with change in mental status (including symptoms such as confusion, disorientation, coma, or inability to talk) and often with new onset of seizures (excluding simple febrile convulsion) in a person of any age at any time of the year (Solomon et al.,2008). Incidence of AES has been reported worldwide. Multiple factors like virus, bacteria, fungi, parasites and toxins may cause AES (2). It is estimated that a population of 375 million are at a risk of acquiring AES in India (3). Besides JE virus (JEV), other viruses that have resulted in high incidence of AES in India are Dengue virus, Entero-virus, Herpes Simplex Virus (HSV), Measles and Chandipura virus
(4). However, etiology of AES remains unknown in $68-75 \%$ of patients (5).

Muzaffarpur district, suffers repeated epidemics of acute encephalopathy in children for the past 16-17 years. Initially the foci of the disease outbreak was limited to the Muzaffarpur district but recent trend shows that its foci has spread to many other districts in Bihar. In 2014, till 17th Oct, 928 case and 314 deaths due to AES was reported from 32 districts of Bihar. The requisite clinical samples were collected from AES patients and sent to National Institute of Virology, Pune and National Communicable Disease Center, New Delhi for virological testing.

These included CSF samples, serum samples, nasal swabs, throat swabs, rectal swabs, urine samples, postmortem brain needle biopsy material by nasal route, and post-mortem liver biopsy specimen over the years. All clinical samples were 
negative for known virus causing acute encephalitis like JE, Nipah, West Nile and Chandipura virus. Some specimens were processed for the discovery of novel agents. However, no agent has been found which can be attributed to the cause of the mystery disease in Muzaffarpur [6].

As yearly and comparative report on epidemiology of AES outbreak in Bihar is scanty, the present report analyses epidemiological trend of AES outbreak in Bihar over the years in order to plan for further intervention for the control of the disease. As the diseases is aggravated by multifactorial causes like poverty, poor environmental sanitation, lack of health education or lack of reporting, role of various other departments may also be crucial for the control of the disease. The report also highlights the possible roles of various departments for control of AES disease outbreak.

\section{Methodology}

This was a record based study where daily reports on AES cases in prescribed format was reported from district surveillance units comprising of Govt Medical College \& Hospitals and few private Hospitals to the State Surveillance Unit. Lab reports for JE IgM ELISA were also collected for recording JE cases. WHO case definition was used for inclusion of cases. Data on JE vaccination coverage was taken from Routine Immunization Cell of State Health Society, Bihar to see the impact of JE vaccination coverage on curbing the AES cases in the State. Descriptive epidemiology based on time, place and person was used to analyze the outbreak trend of AES outbreak in Bihar.

\section{Results \& Discussion}

As of Oct 17, 2014, 928 cases and 314 deaths were reported due to AES out of which 17 were JE positive. Approximately, 941, 1095, 450 cases of AES were reported in 2011-13 respectively in Bihar. The outbreak peak of AES outbreak since last three years was reported in June except in 2011 when it was observed in Sep-Oct. A peculiar feature of the AES outbreak in 2011 was the reporting of many JE cases (181 cases \& 18 deaths) and the outbreak was confirmed to be due to JE. However since last 3 years majority of the AES cases have been reported in June and only 18, 30 and 17 cases of JE positive was reported in 2012-14 respectively. This may indicate the seasonality of the disease outbreak in Bihar and relevant interventions before this month may help in reducing the incidence of AES cases. As the disease is aggravated by multiple factors, inter-sectoral coordination is also needed for its control. Flow chart depicting roles of various departments is mentioned in Fig 1.Date wise cases of
AES as reported in 2014 are mentioned in Fig 2. Muzaffarpur district has been the most affected district since last three years reporting $334,135 \& 357$ cases in 2012-14 respectively. Place wise distribution of AES and vaccination coverage of JE in Bihar in 2014 is mentioned in Table 1. Case Fatality rate due to AES was 20,36, 35 \& 34 in 2012-14 respectively. Age group most affected was 0-4 followed by 5-9 \& 10-14 in 2012-14 respectively except in 2011 when age group 5-9 was the most affected followed by 10-14. Males were more affected than females in majority of the times. Person wise distribution of AES in 2014 is mentioned in Table 2. 81\% of the cases were reported from Govt. Health institutions while $19 \%$ was reported from private institutions. A brief comparative summary of AES outbreaks from 2011 to 2014 is mentioned in Table 3.

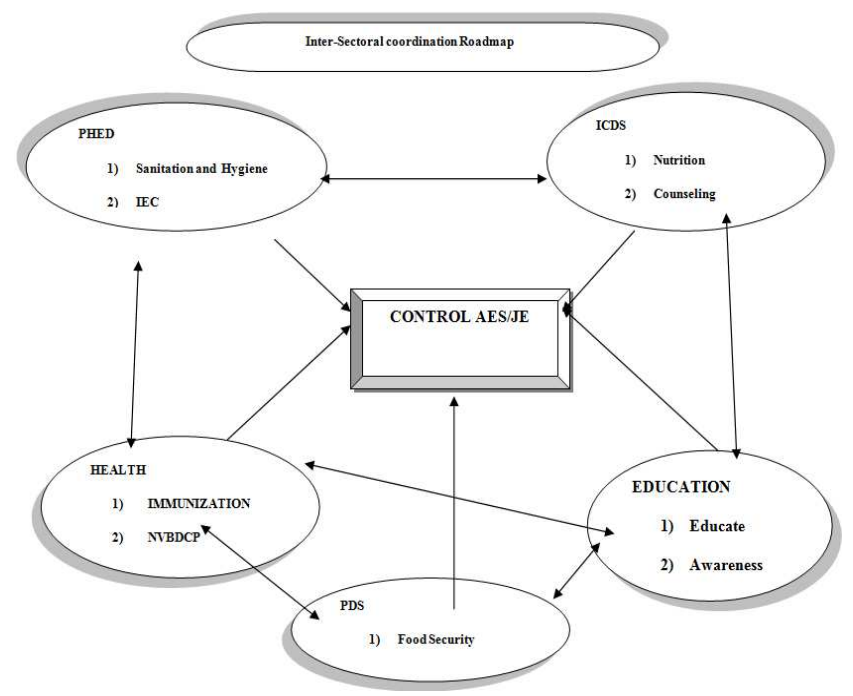

Figure 1. Flow chart for controlling the incidence of mortality and morbidity due to AES/JE in Bihar through inter-sectoral coordination

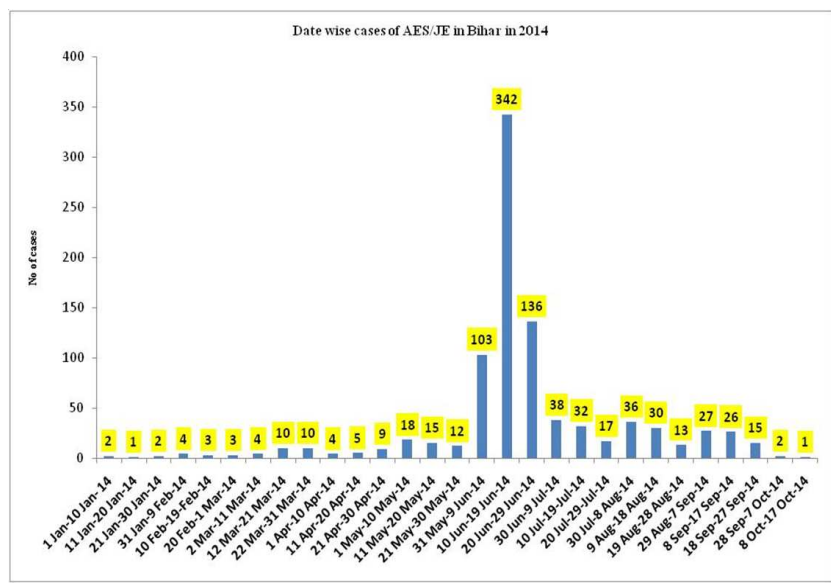

Figure 2. Date wise cases of AES/JE in Bihar in 2014.

Table 1. Place distribution of AES cases in Bihar and JE vaccination coverage in 2014

\begin{tabular}{|c|c|c|c|c|c|c|c|c|c|}
\hline \multicolumn{10}{|c|}{ District wise cases and deaths due to AES/JE including JE vaccination status in 2014 in Bihar } \\
\hline SI No & District & $\begin{array}{l}\text { No of } \\
\text { cases }\end{array}$ & $\begin{array}{l}\text { f No of } \\
\text { deaths }\end{array}$ & $\begin{array}{l}\text { Case Fatality } \\
\text { Rate (CFR) }\end{array}$ & $\begin{array}{l}\text { JE } \\
\text { positive }\end{array}$ & $\begin{array}{l}\text { JE Coverage under } \\
\text { RI ( } 9 \text { months)in } \\
2014 \text { [\%] } \\
\end{array}$ & $\begin{array}{l}\text { JE Coverage under } \\
\text { RI (16 months) in } \\
2014 \text { [\%] }\end{array}$ & $\begin{array}{l}\text { JE Campaign } \\
\text { coverage in } \\
2013-14 \text { [\%] } \\
\end{array}$ & Remarks \\
\hline 1 & ARARIA & 10 & 10 & 100 & 0 & 0 & 0 & 95.5 & Campaign in Nov-Jan 14 \\
\hline
\end{tabular}




\begin{tabular}{|c|c|c|c|c|c|c|c|c|c|}
\hline \multicolumn{10}{|c|}{ District wise cases and deaths due to AES/JE including JE vaccination status in 2014 in Bihar } \\
\hline SI No & District & $\begin{array}{l}\text { No of } \\
\text { cases }\end{array}$ & $\begin{array}{l}\text { No of } \\
\text { deaths }\end{array}$ & $\begin{array}{l}\text { Case Fatality } \\
\text { Rate (CFR) }\end{array}$ & $\begin{array}{l}\text { JE } \\
\text { positive }\end{array}$ & $\begin{array}{l}\text { JE Coverage under } \\
\text { RI ( } 9 \text { months)in } \\
2014 \text { [\%] }\end{array}$ & $\begin{array}{l}\text { JE Coverage under } \\
\text { RI (16 months) in } \\
2014 \text { [\%] }\end{array}$ & $\begin{array}{l}\text { JE Campaign } \\
\text { coverage in } \\
2013-14[\%]\end{array}$ & Remarks \\
\hline 2 & AURANGABAD & 17 & 7 & 41 & 1 & 79 & 18 & 0 & \\
\hline 3 & ARWAL & 5 & 2 & 40 & 0 & 0 & 0 & 99.2 & Campaign in Nov-Jan 14 \\
\hline 4 & BANKA & 0 & 0 & 0 & 0 & 0 & 0 & 95.7 & Campaign in Nov-Jan 14 \\
\hline 5 & BEGUSARAI & 3 & 1 & 33 & 0 & 0 & 0 & 0 & \\
\hline 6 & BHABHUA & 1 & 0 & 0 & 0 & 0 & 0 & 0 & \\
\hline 7 & BHAGALPUR & 1 & 0 & 0 & 0 & 0 & 0 & 95.1 & Campaign in Nov-Jan 14 \\
\hline 8 & BHOJPUR & 16 & 5 & 31 & 0 & 0 & 0 & 95.3 & Campaign in Nov-Jan 14 \\
\hline 9 & BUXAR & 2 & 1 & 50 & 0 & 0 & 0 & 96.5 & Campaign in Nov-Jan 14 \\
\hline 10 & DARBHANGA & 2 & 2 & 100 & 0 & 0 & 0 & 89.7 & $\begin{array}{l}\text { Campaign in Jun-Sep } 14 \\
\text { (P) }\end{array}$ \\
\hline 11 & GOPALGANJ & 5 & 5 & 100 & 1 & 51 & 13 & 0 & \\
\hline 12 & GAYA & 63 & 20 & 32 & 0 & 73 & 28 & 0 & \\
\hline 13 & JAHANABAD & 6 & 2 & 33 & 0 & 0 & 0 & 0 & \\
\hline 14 & JAMUI & 3 & 2 & 67 & 0 & 0 & 0 & 97.4 & Campaign in May-Jun 14 \\
\hline 15 & KHAGARIA & 4 & 0 & 0 & 1 & 0 & 0 & 0 & \\
\hline 16 & KISHANGANJ & 0 & 0 & 0 & 0 & 0 & 0 & 0 & \\
\hline 17 & KATIHAR & 0 & 0 & 0 & 0 & 0 & 0 & 0 & \\
\hline 18 & LAKHISARAI & 4 & 0 & 0 & 1 & 0 & 0 & 94.4 & Campaign in May-Jun 14 \\
\hline 19 & MADHUBANI & 2 & 0 & 0 & 0 & 0 & 0 & 0 & \\
\hline 20 & MADHEPURA & 1 & 1 & 100 & 0 & 0 & 0 & 0 & \\
\hline 21 & MUNGER & 2 & 2 & 100 & 0 & 0 & 0 & 0 & \\
\hline 22 & MUZAFFARPUR & 357 & 91 & 26 & 0 & 43 & 6 & 90.5 & Campaign in Nov-Jan 14 \\
\hline 23 & NAWADA & 14 & 7 & 50 & 0 & 59 & 18 & 97 & Campaign in Nov-Jan 14 \\
\hline 24 & NALANDA & 12 & 7 & 58 & 0 & 0 & 0 & 98.1 & Campaign in Nov-Jan 14 \\
\hline 25 & $\begin{array}{l}\text { WEST } \\
\text { CHAMPARAN }\end{array}$ & 8 & 1 & 13 & 0 & 49 & 8 & 98.7 & Campaign in Nov-Jan 14 \\
\hline 26 & PATNA & 64 & 32 & 50 & 1 & 0 & 0 & 0 & \\
\hline 27 & $\begin{array}{l}\text { EAST } \\
\text { CHAMPARAN }\end{array}$ & 127 & 41 & 32 & 7 & 0 & 0 & 95.1 & Campaign in Nov-Jan 14 \\
\hline 28 & PURNIA & 0 & 0 & 0 & 0 & 0 & 0 & 0 & \\
\hline 29 & ROHTAS & 6 & 3 & 50 & 0 & 0 & 0 & 0 & \\
\hline 30 & SAHARSA & 4 & 1 & 25 & 0 & 0 & 0 & 0 & \\
\hline 31 & SHEKHPURA & 0 & 0 & 0 & 0 & 0 & 0 & 95.1 & Campaign in May-Jun 14 \\
\hline 32 & SHEOHAR & 6 & 2 & 33 & 0 & 0 & 0 & 0 & \\
\hline 33 & SITAMARHI & 60 & 22 & 37 & 0 & 0 & 0 & 0 & \\
\hline 34 & SAMASTIPUR & 35 & 14 & 40 & 0 & 0 & 0 & 93.7 & Campaign in Nov-Jan 14 \\
\hline 35 & SARAN & 22 & 13 & 59 & 1 & 0 & 0 & 96.2 & $\begin{array}{l}\text { Campaign in Jun-Sep } 14 \\
\text { (P) }\end{array}$ \\
\hline 36 & SUPAUL & 0 & 0 & 0 & 0 & 0 & 0 & 0 & \\
\hline 37 & SIWAN & 2 & 0 & 0 & 0 & 72 & 13 & 95.3 & Campaign in Nov-Jan 14 \\
\hline 38 & VAISHALI & 45 & 19 & 42 & 0 & 0 & 0 & 99.2 & Campaign in Nov-Jan 14 \\
\hline 39 & JHARKHAND & 5 & 1 & 20 & 1 & & & & \\
\hline 40 & NEPAL & 4 & 0 & 0 & 3 & & & & \\
\hline & TOTAL & 918 & 314 & 34 & 17 & & & & \\
\hline Overal & 11 TOTAL & 928 & & & & & & & \\
\hline Distric & ct name: NA & 10 & Note: $\mathrm{N}$ & $A=$ Not availabl & $\mathrm{e},(\mathrm{P})=$ prov & visional & & & \\
\hline
\end{tabular}

Table 2. Person wise distribution of AES/JE cases in Bihar during outbreak in 2014 (till 17th Oct)

\begin{tabular}{lll}
\hline Age Group & Frequency & \% \\
\hline $0-4$ & 489 & 54 \\
$5-9$ & 324 & 36 \\
\hline
\end{tabular}




\begin{tabular}{lll}
\hline $10-14$ & 95 & 10 \\
$15-19$ & 2 & 0.2 \\
$20+$ & 0 & 0 \\
Total & 910 & \\
Data NA & 18 & \\
Sex & Frequency & $\%$ \\
Male & 513 & 55 \\
Female & 415 & 45 \\
Total & 928 & \\
\hline
\end{tabular}

Table 3. Year wise Comparison of AES/JE outbreak in Bihar

\begin{tabular}{|c|c|c|c|c|c|}
\hline \multicolumn{6}{|c|}{ Comparison of AES/JE outbreak in 2011, 2012, 2013 \& 2014 in Bihar } \\
\hline SI No & Epidemiological indices & 2011 & 2012 & 2013 & 2014 \\
\hline \multirow{5}{*}{ 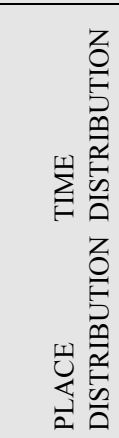 } & Date of start of outbreak & 23-Jul & 16-May & 6-Apr & 31-May \\
\hline & Outbreak peak & $\begin{array}{l}21 \text { Sep to } 25 \text { Oct } \\
\text { ( } 523 \text { cases) }\end{array}$ & $\begin{array}{l}5 \text { Jun to } 27 \text { Jun }(555 \\
\text { cases) }\end{array}$ & 5 Jun to 14 Jun & 10 Jun to 19 Jun \\
\hline & $\begin{array}{l}\text { Date from which outbreak } \\
\text { peak declined rapidly }\end{array}$ & 14-Nov & $16-\mathrm{Nov}$ & 12-Sep & 1-Jul \\
\hline & Date of end of outbreak & 4th Dec & 31-Dec & 21-Dec & 17-Oct \\
\hline & $\begin{array}{l}\text { District with maximum } \\
\text { incidence of } \mathrm{AES} / \mathrm{JE}\end{array}$ & $\begin{array}{l}\text { Gaya }(298 \\
\text { case })>\text { Patna }(114 \\
\text { case })>\text { Aurangabad } \\
(65 \text { case })>\text { Saran }(61 \\
\text { case })\end{array}$ & $\begin{array}{l}\text { Muzaffarpur ( } 334 \\
\text { cases) }>\text { Patna }(182 \\
\text { case })>\text { E Champaran } \\
=\text { Sitamarhi }(58 \\
\text { case) }>\text { Vaishali ( } 57 \\
\text { case) }>\text { Gaya ( } 44 \text { case) }\end{array}$ & $\begin{array}{l}\text { Muzaffarpur }(135 \\
\text { case })>\text { Patna }(53 \\
\text { case })>\text { E Champaran } \\
(32 \text { case })>\text { Sitamarhi } \\
(20 \text { case })\end{array}$ & $\begin{array}{l}\text { Muzaffarpur ( } 357 \\
\text { case) }>\text { E } \\
\text { Champaran }>\text { Patna } \\
(64)>\text { Gaya }(63)\end{array}$ \\
\hline \multirow{7}{*}{ 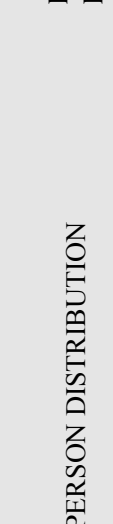 } & $\begin{array}{l}\text { Total cases reported due to } \\
\text { AES }\end{array}$ & 941 & 1095 & 450 & 928 \\
\hline & $\begin{array}{l}\text { Total deaths reported due to } \\
\text { AES }\end{array}$ & 187 & 395 & 159 & 314 \\
\hline & Case Fatality Rate/100 & 20 & 36 & 35.33 & 34 \\
\hline & $\begin{array}{l}\text { Total JE positive cases during } \\
\text { the outbreak }\end{array}$ & 181 & 18 & 30 & 17 \\
\hline & $\begin{array}{l}\text { Total JE positive deaths } \\
\text { during the outbreak }\end{array}$ & 21 & 0 & 0 & 0 \\
\hline & Age group most affected & $\begin{array}{l}5-9(395 \text { case })>10- \\
14(277 \text { case })>0-4 \\
(241 \text { case })\end{array}$ & $\begin{array}{l}0-4(561 \text { case })>5-9(374 \\
\text { case })>10-14(132 \text { case })\end{array}$ & $\begin{array}{l}0-4(222 \text { case })>5-9 \\
(142 \text { case })>10-14(64 \\
\text { case })\end{array}$ & $\begin{array}{l}0-4(489 \text { case })>5-9(324 \\
\text { case })>10-14(95 \text { case })\end{array}$ \\
\hline & Sex most affected & $\begin{array}{l}\text { Male }(530 \\
\text { cases })>\text { Female ( } 411 \\
\text { case) }\end{array}$ & $\begin{array}{l}\text { Female }(603 \text { case })>\text { Male } \\
(491 \text { case })\end{array}$ & $\begin{array}{l}\text { Male }(255 \\
\text { case })>\text { Female }(185 \\
\text { cases })\end{array}$ & $\begin{array}{l}\text { Male (513)>Female } \\
(415)\end{array}$ \\
\hline
\end{tabular}

As per Govt of India guidelines, JE vaccination was undertaken in 7 districts from 2010-14 under routine immunization viz: W Champaran, Gaya, Muzaffarpur, Gopalganj, Siwan \& Nawada. Thereafter in many districts JE vaccination was undertaken in campaign mode in 24 districts Analysis reveals that although JE cases have come down in the districts where JE vaccination was pursued, it has little impact on curbing AES cases in the State.

The requisite clinical samples were collected from AES patients and sent to National Institute of Virology, Pune and National Communicable Disease Centre, New Delhi for virological testing. These included CSF samples, serum samples, nasal swabs, throat swabs, rectal swabs, urine samples, post-mortem brain needle biopsy material by nasal route, and post-mortem liver biopsy specimen over the years. All clinical samples were negative for known virus causing acute encephalitis like JE, Nipah, West Nile and Chandipura virus. Some specimens were processed for the discovery of novel agents. However, no agent has been found which can be attributed to the cause of the mystery disease labelled as AES.

\subsection{Policy Perspectives for Future Action with Regard to Control of AES}

As the diseases is aggravated by multifactorial causes like poverty, poor environmental sanitation, lack of health education or lack of reporting, role of various other departments may also be crucial for the control of the disease.

\subsection{Steps Taken at National Level}

Guidelines and protocol for AES surveillance, treatment protocol and case management has been developed by National Vector Borne Disease Control Programme (NVBDCP), Govt. of India and circulated to the States. Government of India constituted a Group of Ministers (GoM) 
[Health \& FW, Drinking Water Supply \& Sanitation, Women \& Child Development, Social Justice \& Empowerment, Rural Development, Urban Development] to look into incidence of AES. Rs 4,000 crores are being allocated (7) for National Encephalitis Control Programme which includes replacement of shallow hand pumps by deep bore hand pumps in acute encephalitis syndrome-affected districts, setting up of Intensive Care Unit wards, especially for JE patients, in all district hospitals and identifying the most undernourished children and providing them better nutrition to fight the virus. It will first be implemented in 60 districts in West Bengal, Bihar, Uttar Pradesh, Tamil Nadu and Assam (8). The Global Disease Detection Program (GDD) is the Centre for Disease Control and Prevention's (CDC's) (USA) that has started Global Disease Detection India Centre (GDDIC) at Delhi recently. Workshops for formulating prospective surveillance for establishing the diagnosis of AES has also been undertaken.

\subsection{Steps Taken at State Health Department Level}

'Health Alerts' including all necessary guidelines and protocols for AES control and management is issued to all the districts and Govt MC \& Hospitals much before the peak outbreak season (June) over the years. AES task force has been constituted comprising of experts from Health as well as Non-Health Department in the State. Prescribed format for reporting is available. Sentinel sites for JE diagnosis has been formed in Six Govt Medical College \& Hospitals in Bihar viz: PMCH \& NMCH, Patna, SKMCH, Muzaffarpur, JLNMCH, Bhagalpur, ANMCH, Gaya and $\mathrm{DMCH}$, Darbhangha. Free diagnosis of JE is done at these sites. Memorandum of Agreement (MoA) for establishing ICMR field centre for control of JE is under process with Govt. of India. Nearest relatives of deceased child due to $\mathrm{AES} / \mathrm{JE}$ are provided an economic support of Rs 50,000 through Chief Minister Relief fund. Standard Operating Protocol (SOP) is available for AES/JE control. State control room for AES/JE control is also formed. 15 districts in Bihar were selected by Govt. of India for carrying out specific activities for AES/JE control in 2012-13 viz: Araria, Darbhangha, E. Champaran, Gaya, Gopalganj, Jahanabad, Muzaffarpur, Nalanda, Nawada, Patna, Samastipur, Saran, Vaishali and W Champaran. JE vaccination under routine immunization as well as in campaign mode is also planned and implemented (9).

\subsection{Challenges}

As etiological diagnosis of the disease is not available early referral for case management may be crucial in handling the cases. Participation and involvement of other non-health departments is practically very difficult and much needs to be done on this front. Laboratory facilities for diagnosis are very poor. There is lack of efficient crosschecking mechanisms and inadequate and poorly supervised surveillance with respect to AES in the State. Underreporting is also one of the constraints. Participation of private hospitals, especially in the corporate sector in reporting of AES cases is very poor. Active surveillance must be strengthened to eliminate this error. Poor socio-economic conditions of the affected population are also a challenge. Majority of the childrens suffering from the disease are malnourished that upsurges the need for inter-sectoral coordination.

\subsection{Inter-Sectoral Coordination for AES/JE Control}

Role of various key departments:

a. I.C.D.S (Integrated Child Development Scheme )

- Targeting children below three years more effectively and promote infant and young child nutrition practices and micronutrient supplementation.

- Special focus would be given to children from disadvantage sections (Mahadalit tola).

- Strengthening basic facilities and service delivery in Anganwadi centres (AWCS).

b. P.H.E.D ( Public Health and Engineering Department)

- Attainment of full sanitation coverage in rural areas.

- Adoption of hygiene practices at personal, family, and community level.

- The sustainability of drinking water sources.

- IEC activities.

c. Education

- Focus on elementary education of satisfactory quality with emphasis on education for life.

- To bridge social, regional and gender gaps.

- Focus on the educational participation of children from the SC/ST, religious and linguistic minorities.

- Promoting community participation.

d. P.D.S (Public Distribution System)

- Providing food grains and other essential items to vulnerable sections of the society at reasonable (subsidized) prices.

- To put an indirect check on the open market prices of various items.

- To attempt socialization in the matter of distribution of essential commodities.

- Apart from the above departments, many other departments can also play a crucial role for the control of the disease like:

e. Animal Husbandry Department

- Assessment of pig density in relation to human density in the affected areas, sending nasal swabs from infected piglets for viral isolation to labs etc),

f. Road \& Building Construction Department

- Ensuring better construction of roads and buildings with proper drainage to prevent vector breeding sites).

g. Municipality:

- Ensuring fogging and cleanliness in urban areas for control of vector etc.

Roles of various departments as mentioned above are depicted in Figure 1 below. 


\section{Conclusion}

The current AES/JE surveillance system should be strengthened including efficient cross-checking mechanism so that only correctly diagnosed AES cases are received. The effect of interventions undertaken for AES control should be properly monitored and supervised to avoid wastage of public health resources. Gaps and challenges in control of AES outbreak constitute key lessons that need to be incorporated as strategic planning. Laboratory facilities need strengthening. Micro- planning before the AES transmission season needs to be strictly implemented. As the disease outbreak is aggravated by multi-factorial factors, intersectoral coordination with various departments may also prove to be effective in the control of the disease outbreak.

\section{Recommendations}

1) Anticipatory preparations should be made for timely availability of medicines, equipments etc. Microplanning involving awareness among the health \& Surveillance workers for prompt reporting of the cases should be undertaken. Orientation training to all these and Medical officers as well as key officials of nonhealth department members should also be undertaken.

2) More number of Health Facilities should be identified for clinical management of AES/JE cases which should ensure the availability of necessary drugs, IV fluids and equipments before the onset of JE transmission season.

3) District and Block Rapid Response Team (RRT) should be activated for investigation and containment of the outbreak. This should include the Animal Husbandry Department as well.

4) Primary Health Centres (PHCs) should also be made well equipped to manage any outbreak. For this Technical Malathion, fogging machines, health education materials, transportation of cases to referral centres should be made available before the transmission season. 2004.

5) Vector and larval surveillance should be carried out throughout the year to map the vector density and larval breeding sites.

6) Case management through early diagnosis and prompt treatment must be done. Camp based approach for active case search of AES/JE must be Diagnostic undertaken

7) Vaccination of susceptible population should be carried out on urgent basis at least before the transmission season.

8) Awareness of Community through Information, Education \& Communication (IEC), Inter-Personal communication (IPC) and Behaviour Change Communication (BCC) must be done for success of intervention methods.

9) Surveillance system must be strengthened and data analysis work should be carried out on regular basis. Coordination and data sharing between District
Surveillance Unit and District Programme officers of Control Programmes must be done on regular basis. Every single case of AES/JE should be reported immediately to the higher authority to prevent outbreak.

10)All districts adjoining the districts where a case of JE/AES has been recorded should be made alert an eye on all the AES cases for timely referral and case management should be done.

11)Fogging should be carried on a regular basis to lessen the burden of JE cases among the AES cases.

12)Reporting of JE vaccination should be undertaken from session site to $\mathrm{PHC}$ and, from $\mathrm{PHC}$ to district level on regular basis. For this purpose reporting format should be distributed to all the reporting units in advance. Apart from this, report of outbreaks should also be sent to the upper level; by district level Integrated Disease Surveillance Programme (IDSP) team. Regular monitoring should be undertaken of the services provided to the community to achieve our target, through different departments. District Surveillance Committee has already been formed under IDSP to control any epidemics with different departments under the chairmanship of District Magistrate. Monthly meeting for discussing the micro plan for AES/JE control should be held at regular interval and at least 3 months before the AES/JE outbreak season (June for the last three years).

\section{Acknowledgments}

The authors are thankful to State and district Vector-Borne Disease Control Programme and Integrated Disease Surveillance Programme team including Govt Medical College \& Hospitals in Bihar for providing technical inputs and valuable data. Thanks are also due to State Routine Immunization Cell, State Health Society, Bihar for providing valuable data for JE vaccination coverage.

\section{References}

[1] Self, L.S., H.K. Shin, K.H. Kim, K.W. Lee, C.Y. Chow H.K. Hong, 1973. Ecological studies on Culex tritaeniorhynchus as a vector of Japanes encephalitis, Bull World Health Organ. 49(1): 41-47.

[2] Jmor F, Emsley HCA, Fischer M, etal. The incidence of acute encephalitis syndrome in Western industrializes and tropical countries. Virol J. 2008; 5:134

[3] Potharaju NR. Incidence rate of AES without specific treatment in India and Nepal. Indian J Comm Med, 2012, $37: 240-251$

[4] Saxena SK, Mishra N, Saxena R, etal. Trend of Japanese Encephalitis in North India:evidence from 38 AES patients and approval of niceties. J Infect Dev Ctries, 2009; 30:517-530

[5] Kennedy PG Viral encephalitis: causes, differential diagnosis \& management. J. Neurol Neurosurgery Psychiatry. 2004; 75:10-15 
410 Ragini Mishra and Ganga Kumar: Epidemiological Report on Acute Encephalitis Syndrome (AES)/Japanese Encephalitis (JE) Outbreak in Bihar \& Planning Perspectives for Its Control

[6] National Institute of Virology. Report on investigation of an outbreak of acute encephalitis syndrome (AES) in Muzaffarpur, Bihar. Director, National Institute of Virology, Pune. NIV/MCC/EPD/755, November 23, 2011.

[7] Drive to combat JE soon. Statement of Union Health Minister, Govt. of India. Available from:http:// times of indiatimes.com/india/Drive to combat JE soon/article show/11140076 cms. The Times of India, Dec 17, 2011.
[8] Rs 4,000 crores plan to tackle encephalitis? Oct 17, 2012, Available from http://www.firstpost.com/india/rs-4000-crplan-to tackle encephalitis-494189.html.

[9] Annual report 2012-13 available at www.statehealthsocietybihar.org., site accessed in Nov 2014 